\title{
Przygotowanie logopedy do pracy z dzieckiem z rozszczepem wargi i/lub podniebienia. Projekt modelu kształcenia
}

\author{
Preparing Speech Therapists for Work Children with a Cleft Lip \\ and/or Cleft Palate. Educational Model Design
}

\begin{abstract}
Słowa kluczowe: zaburzenia mowy osób z rozszczepem, dyslalia rozszczepowa, alalia rozszczepowa, kształcenie logopedów
\end{abstract}

Keywords: speech disorders in people with cleft, cleft dyslalia, cleft alalia, education of speech therapists

\section{Streszczenie}

W artykule przedstawiono projekt modelu kształcenia logopedycznego w zakresie diagnozy i terapii zaburzeń mowy u dzieci z rozszczepem wargi i/lub podniebienia. Podjęto rozważania dotyczące czasu realizacji omawianego modułu zajęć, biorąc pod uwagę cały cykl kształcenia logopedycznego, niezbędnych umiejętności, z jakimi student powinien przystąpić do proponowanych wykładów i ćwiczeń, a także przedstawiono listę zagadnień do realizacji. Projekt może być wykorzystany do opracowania szczegółowych strategii kształcenia logopedycznego podczas studiów stacjonarnych i podyplomowych, jak również różnych form doskonalenia zawodowego.

\footnotetext{
* Uniwersytet Łódzki, Wydział Filologiczny, Instytut Filologii Polskiej i Logopedii, Zakład Dialektologii Polskiej i Logopedii, ul. Pomorska 171/173, 90-236 Łódź, e-mail: danuta.pluta@uni.lodz.pl, ORCID: https://orcid.org/0000-0003-0425-6006.
} 


\section{Abstract}

The article presents a design of a speech therapy educational model for the diagnosis and therapy of speech disorders in children with cleft lip and/or cleft palate. The issue of time of the implementation of this therapy model has been considered, taking into account the entire cycle of speech therapy education as well as the crucial skills with which the student should start the proposed lectures and classes. Besides, a list of issues to be implemented has been presented. The model can be used to develop detailed speech therapy education strategies during full-time and postgraduate studies, as well as various forms of professional development.

\section{Wprowadzenie}

Logopedia jako nauka i działalność praktyczna zmieniała się na przestrzeni lat. Obecnie logopedzi często zajmują się dziećmi w pierwszym roku życia, w tym noworodkami czy niemowlętami z wadą w obrębie środkowej części twarzoczaszki. Pomimo znacznego rozwoju logopedii jako nauki i działalności praktycznej kształcenie $\mathrm{w}$ zakresie postępowania $\mathrm{z}$ pacjentem $\mathrm{z}$ wadą rozszczepową nie zawsze wydaje się wystarczające, co budzi niepokój. Wielu młodych logopedów, którzy ukończyli studia w różnych ośrodkach, mniej lub bardziej wyraźnie wyraża opinię o braku wystarczającej wiedzy i umiejętności dotyczących pacjenta $\mathrm{z}$ wadą $\mathrm{w}$ obrębie środkowej części twarzoczaszki.

Przedmiotem opracowania jest postępowanie logopedyczne $\mathrm{z}$ dzieckiem $\mathrm{z}$ rozszczepem wargi i/lub podniebienia. Zagadnienie to zostanie przedstawione z perspektywy niezbędnej wiedzy, którą powinien mieć logopeda, aby na jej bazie budować odpowiednie umiejętności praktyczne. Kolejne wątki analizy będą uwzględniać obszary wiedzy związanej z osobami z rozszczepem wargi i podniebienia, odnoszące się do medycyny, lingwistyki, psychologii, a także ściśle logopedii. Pragnę przedstawić także katalog najważniejszych umiejętności praktycznych, które są niezbędne w pracy z pacjentem $\mathrm{z}$ wadą $\mathrm{w}$ obrębie środkowej części twarzoczaszki i z jego rodziną.

Nadrzędnym celem artykułu jest ukazanie, w jaki sposób kształcić logopedów, aby nie tylko wiedzieli, jak pomagać dzieciom $\mathrm{z}$ rozszczepem wargi i/lub podniebienia, ale także potrafili to robić. Niektóre z zagadnień, czy też ich wątki wiążące się z podjętym tematem, są $\mathrm{w}$ różnym zakresie omawiane $\mathrm{w}$ innych publikacjach prezentujących sposoby pomocy osobom dotkniętym dysfunkcją mowy wynikającą głównie - jeśli nie wyłącznie - z występowania wady w obrębie środkowej części twarzoczaszki. Trudno jednak w niniejszym opracowaniu omawiać szczegółowo na przykład poszczególne etapy czy kierunki diagnozy i terapii, gdyż z jednej strony przerasta to ramy niniejszego artykułu, $\mathrm{z}$ drugiej zaś jego tematem jest sposób kształcenia logopedów, a nie przekazywanie czytelnikowi wiedzy i umiejętności dotyczących 
postępowania logopedycznego. Kształcenie logopedów oraz prowadzenie diagnozy i terapii logopedycznej to dwa różne zagadnienia.

Propozycja modelu kształcenia logopedów w zakresie diagnozy i terapii zaburzeń mowy osób z rozszczepem według mnie powinna uwzględniać:

- optymalny czas, w jakim należałoby zapoznawać studentów z wiedzą i umiejętnościami związanymi z omawianą dysfunkcją mowy, mając na uwadze cały cykl kształcenia w zakresie logopedii, z jakim mamy do czynienia podczas studiów licencjackich i magisterskich lub studiów podyplomowych (o tych ostatnich będzie mowa w niewielkim zakresie);

- zakres wiedzy lingwistycznej, medycznej, psychologicznej i logopedycznej, jaki należy przekazać studentom, $\mathrm{z}$ uwzględnieniem najnowszych wyników badań dotyczących zaburzeń mowy osób z rozszczepem;

- określenie szczegółowych umiejętności praktycznych związanych z diagnozą i terapią, a także koniecznych kompetencji społecznych;

- wskazanie metod i form kształcenia.

Istotne jest także, aby kształcenie logopedyczne w zakresie procedur stosowanych w przypadku osób z rozszczepem wargi i/lub podniebienia nawiązywało do Standardu postępowania logopedycznego w przypadku rozszczepu wargi i podniebienia zawartego w ważnym dla logopedów opracowaniu, które przedstawia modelowe schematy diagnozy i terapii zaburzeń mowy określonego typu [Pluta-Wojciechowska, 2015]. Przywołany standard dotyczący osób z wadą w obrębie środkowej części twarzoczaszki otwiera wprowadzenie uwzględniające podstawową wiedzę medyczną związaną z rozszczepem wargi i/lub podniebienia, a także typologię zaburzeń mowy w przypadku tej wady rozwojowej. W kolejnych częściach opracowania autorka prezentuje poszczególne wątki diagnozy, a następnie terapii logopedycznej małych, a także starszych dzieci. Stosowanie tego standardu postępowania diagnostycznego i terapeutycznego stawia przed logopedą wysokie wymagania. Wiążą się one $\mathrm{z}$ wszechstronną wiedzą o mechanizmie zaburzeń, koniecznością uwzględniania procedur medycznych, a także podejścia kompleksowego do pacjenta $\mathrm{z}$ wadą rozszczepową.

Opracowanie ogólnych ram modelu kształcenia w zakresie postępowania logopedycznego $\mathrm{z}$ pacjentami z rozszczepem nie jest łatwe $\mathrm{z}$ uwagi na wielość czynników determinujących zaburzenia mowy charakterystyczne dla osób z omawianą wadą, a także na zakres specjalistycznej wiedzy medycznej, jaka jest niezbędna podczas diagnozy i terapii logopedycznej, konieczność powiązania wiedzy płynącej z różnych dyscyplin - lingwistyki, laryngologii, chirurgii, foniatrii, psychologii, logopedii - podczas interpretacji zaburzeń mowy u osób z rozszczepem podniebienia oraz projektowania i prowadzenia terapii. Stąd przygotowany model kształcenia jest projektem, który zawiera ogólne wytyczne, jakie mogą być przydatne do opracowania szczegółowej strategii kształcenia. Mam nadzieję, że konkretne rozwiązania zostaną opracowane podczas dyskusji w gronie specjalistów. 
W najnowszej typologii zaburzeń mowy [Grabias, 2019; por. 2012; 2015] dysfunkcje mowy osób z rozszczepem zostały umieszczone w grupie zaburzeń mowy o etiologii związanej z brakiem lub niedowładem sprawności realizacyjnych. Została im przypisana nazwa dysglosja, co oznacza, że wadę w obrębie środkowej części twarzoczaszki traktuje się jako przyczynę zaburzeń realizacji fonemów. To ważna perspektywa analizy skutków wady rozszczepowej. Podobne ujęcie odnajdujemy w typologii Ireny Styczek [1981].

W polskich publikacjach problematyka mowy rozszczepowej nie jest często poruszanym tematem, w szczególności w aspekcie prowadzonych badań, uwzględniających metodykę logopedyczną, co podkreślam [np. Antkowski, 1957; 1960, Łyżyczka, 1978; Kwiecień, Dudkiewicz, 1996; Pluta-Wojciechowska, 2006; 2010; 20111․ Wiedza o dysfunkcjach mowy się zmienia, co ma związek z prowadzonymi badaniami [np. Mierzejewska, Emiluta-Rozya, 1997; Pluta-Wojciechowska, 2006, 2010, 2011, 2019a; Emiluta-Rozya, 2012]. Upoważniają one do dopełnienia typologii zaburzeń mowy osób z rozszczepem, jaką proponowali Irena Styczek [1981] i Stanisław Grabias [2012; $2015 ; 2019]$. Ma to istotne znaczenie nie tylko dla diagnozy, ale też dla terapii logopedycznej. Dla przykładu moje badania empiryczne z 2011 roku wykazały, że zaburzenia mowy obserwowane $\mathrm{u}$ dzieci $\mathrm{z}$ wadą rozszczepową mogą przyjąć formę dyslalii rozszczepowej lub alalii rozszczepowej [Pluta-Wojciechowska, 2011].

\section{Diagnoza i terapia osób z rozszczepem w programie kształcenia logopedycznego}

Analizując programy kształcenia logopedycznego odbywającego się podczas studiów stacjonarnych, na pozór wydaje się, że zaburzenia mowy osób z rozszczepem mogą być omawiane podczas realizacji modułu Dyslalia ${ }^{2}$, gdyż najczęstszą formą dysfunkcji u osób z wadą w obrębie środkowej części twarzoczaszki są zaburzenia realizacji fonemów. Jednakże w wielu programach kształcenia logopedycznego termin $d y$ slalia pojawia się obok terminu alalia (przedmiot nosi nazwę Dyslalia, alalia), co oznacza, że dyslalia jest traktowana jako zejściowa postać alalii [por. Grabias, 2019].

\footnotetext{
1 Przygotowany wykaz uwzględnia publikacje, których autorzy prowadzili badania dotyczące diagnozy i terapii zaburzeń mowy osób z rozszczepem wargi i podniebienia w ujęciu logopedycznym. Stąd w przedstawionej liście brak autorów badań prowadzonych z perspektywy foniatrycznej [zob. np. Hortis-Dzierzbicka, 2004]. Takie ujęcie wynika z przedmiotu opracowania, jakim jest kształcenie logopedów. Oczywiście, że podczas kształcenia logopedów należy zapoznać studentów również z perspektywą foniatryczną, a także pokazać różnice pomiędzy badaniem foniatrycznym a logopedycznym. O różnicach pomiędzy tymi ujęciami zaburzeń realizacji fonemów pisałam obszernie w innych publikacjach [Pluta-Wojciechowska, 2013; 2019a].

2 Należy podkreślić, że termin dyslalia w polskiej logopedii ma różne znaczenia [por. np. Styczek, 1981; Mierzejewska, Emiluta-Rozya, 1997; Emiluta-Rozya, 2012; Grabias, 2012; 2015; 2019].
} 
Takie ujęcie - mówiąc ogólnie - odnajdujemy w opracowaniach I. Styczek [1981] oraz S. Grabiasa [2012; 2015; 2019]. Przy tym przyczyną alalii, która „przechodzi” w dyslalię - w ujęciu I. Styczek [1981] - jest opóźnione wykształcenie się pewnych struktur mózgowych. Oznacza to, że dyslalia z takiej perspektywy nie dotyczy zaburzeń realizacji fonemów determinowanych wadliwą budową wargi i/lub podniebienia. Zazwyczaj podczas kształcenia w zakresie przedmiotu Dyslalia, alalia wykładowca poszerza krąg przyczyn warunkujących wadliwą wymowę i omawia - obok korowych - także obwodowe. Uważam, że to dobry zabieg, gdyż student ma możliwość poznania różnych ujęć terminu dyslalia. Warto jednak zauważyć, że w najnowszej typologii zaburzeń mowy S. Grabias opisuje alalię i dyslalię w następujący sposób:

\begin{abstract}
[...] kompetencje nie wykształcają się w ogóle lub wykształcają się w stopniu niewystarczającym do prawidłowej realizacji wypowiedzi w związku z centralnymi zaburzeniami przetwarzania słuchowego, w wyniku których powstają trudności w rozpoznawaniu dźwięków (zaburzenia słuchu fonetycznego i fonologicznego). Alalia dotyczy niedokształcenia wszystkich kompetencji języka i ujawnia się w postaci opóźnienia rozwoju mowy, w dyslalii zaś niedokształcona jest struktura fonologiczna języka. Nieprawidłowość ta prowadzi do zaburzeń wymowy [Grabias, 2019, s. 299].
\end{abstract}

Można się jednak zastanawiać, czy poszerzenie kategorii przyczyn zaburzeń wymowy podczas realizacji modułu Dyslalia, alalia o uwarunkowania wynikające z wady rozszczepowej jest na wczesnym etapie kształcenia logopedycznego możliwe, konieczne i służy rozwijaniu wiedzy i umiejętności studenta logopedii.

Moje wieloletnie doświadczenia związane z kształceniem logopedów pokazują, że nie jest to jednoznacznie zabieg korzystny. Dzieje się tak, ponieważ podczas realizacji modułu Dyslalia, alalia (zazwyczaj na II roku studiów licencjackich) studenci poznają podstawowe zagadnienia dotyczące diagnozy i terapii zaburzeń wszystkich podsystemów języka w przypadku nieprawidłowości o charakterze korowym, występujących u dzieci, w tym także zaburzeń systemu fonetycznego. Muszą zatem połączyć wiedzę lingwistyczną, medyczną, psychologiczną i ściśle logopedyczną, aby zrozumieć diagnozę i terapię logopedyczną dzieci z alalią, która, wycofując się, przybiera formę dyslalii. Jeśli do przyczyn korowych zaburzeń wymowy doda się jeszcze przyczyny obwodowe - także związane z rozszczepem - to młodzi adepci sztuki logopedycznej mogą napotkać poważne problemy dotyczące nie tylko badania, ale także opisu zaburzeń realizacji fonemów u osób z wadą w obrębie środkowej części twarzoczaszki. Co więcej, w przypadku małych dzieci z tą wadą wczesna interwencja logopedyczna wymaga wysoce specjalistycznych i rozważnych działań, na przykład związanych z karmieniem małego dziecka, przygotowaniem go do operacji, podejmowaniem kluczowych decyzji terapeutycznych odnoszących się do priorytetowych celów i zadań terapii logopedycznej, w zależności od stanu procesów percepcyjnych i realizacyjnych. Nie są to zadania proste także dla doświadczonych logopedów. 
Realizacji trudnych zadań związanych z diagnozą logopedyczną nie ułatwia niejednolitość ujęcia zaburzeń realizacji fonemów w polskiej logopedii, o czym pisałam, wskazując na tradycyjny i nowy model diagnozy, a następnie terapii logopedycznej [Pluta-Wojciechowska, 2019a; 2019b; 2020; zob. także Ostapiuk, 2013a; 2013b]. Stąd rozsądne wydaje się, aby podczas realizacji przedmiotu Dyslalia, alalia na wstępie studenci poznali różne ujęcia dyslalii w polskiej logopedii. Istotne jest również poznanie metod badania i opisu wymowy, a także różnych mechanizmów determinujących obserwowane zaburzenia - innych w przypadku działania patogennych czynników korowych (np. zaburzenia słuchu fonemowego), a innych w przypadku anomalii obwodowych anatomicznych (np. ankyloglosja, wada zgryzu), jak również o charakterze funkcjonalnym (zaburzenia czynności prymarnych).

Proponuję zatem, aby zapoznawanie studentów z zasadami diagnozy i terapii zaburzeń mowy osób z rozszczepem odbywało się po realizacji modułu Dyslalia, alalia (co ma miejsce na niektórych uczelniach) - najlepiej po odbyciu przez studentów praktyk, tak aby niełatwa wiedza na temat mechanizmu zaburzeń realizacji fonemów u osób z rozszczepem była budowana na bazie kompetencji dotyczących podstaw diagnozy w przypadku alalii i dyslalii. Dobrym momentem na realizacje tematyki związanej z wadą rozszczepową są studia II stopnia. Osobnej dyskusji wymaga sposób realizacji tego zagadnienia. W programach studiów logopedycznych różnych uczelni treści dotyczące zaburzeń mowy w przypadku wady rozszczepowej są realizowane podczas modułu Dysglosje lub modułów Palatolalia albo Mowa osób z rozszczepem podniebienia. W tym zakresie istnieje duża różnorodność związana zarówno z czasem realizacji omawianego modułu kształcenia, jak i jego nazwą.

\section{Wyjściowa wiedza i umiejętności niezbędne do kształcenia w zakresie zaburzeń mowy osób z rozszczepem wargi i/lub podniebienia}

Zaburzenia mowy osób z rozszczepem wargi i/lub podniebienia mają wieloczynnikową etiologię oraz objawiają się w różnych formach: dyslalii rozszczepowej i alalii rozszczepowej. Postawienie diagnozy logopedycznej obejmującej badanie realizacji fonemów oraz wyjaśnienie przyczyn stwierdzonych zaburzeń u osób z tą wadą nie jest łatwe także w przypadku doświadczonych logopedów. Dzieje się tak, gdyż objawy wad wymowy obejmują wszystkie formy spotykane w innych typach dyslalii obwodowej, a także rozmaite objawy obserwowane rzadko, na przykład zaburzenia rezonansu oraz specyficzne dla osób z rozszczepem symptomy: współruchy mimiczne twarzy, realizacje poza jamą ustną - zwarcia oraz szczeliny gardłowe i krtaniowe [Trost, 1981; Wyatt i wsp., 1996; Kuehn, Karlind, 2000; Nikhila, Prasad, 2017; por. Hardin-Jones, Jones, 2005]. 
Należy pamiętać, że u pacjenta z rozszczepem występują odmienności budowy podniebienia i wargi nie tylko przed, ale i po operacji chirurgicznej, jak również wady zgryzu, zaburzenia układu adenoidalnego, u wielu dzieci niedosłuch, a także zaburzenia czynności prymarnych. Szczególna wiedza jest niezbędna, aby określić mechanizm zaburzeń w przypadku nosowania otwartego, zwarć i szczelin krtaniowych oraz zwarć i szczelin gardłowych. Kluczowe dla rozwoju mowy i terapii jest również ustalenie w gronie specjalistów działań postdiagnostycznych, w tym ewentualnej powtórnej operacji podniebienia - faryngoplastyki w przypadku dzieci $\mathrm{w}$ wieku poniemowlęcym i przedszkolnym $\mathrm{z}$ nosowaniem otwartym strukturalnym [zob. np. Hortis-Dzierzbicka, 2004]. Istotne zadania wymagane są w odniesieniu do małych dzieci z rozszczepem - w pierwszym roku życia, przed i po podstawowej operacji chirurgicznej, a także po kolejnych, o charakterze uzupełniającym. Dotyczą one nie tylko mowy i komunikacji, ale również oddychania, odżywiania, przygotowania do podjęcia nauki szkolnej, rozwoju nie tylko systemu fonemowo-fonetycznego, ale także innych podsystemów języka.

Nakreślone w sposób ogólny szczególne zadania logopedy związane z diagnozą i terapią osób z rozszczepem pozwalają na uwagę, że kształcenie przyszłych logopedów w tym zakresie powinno odbywać się na bazie zdobytej już wiedzy i umiejętności związanych na przykład $\mathrm{z}$ dyslalią i alalią. Można zatem sformułować następujące obszary wiedzy i katalog umiejętności, jakie powinni prezentować studenci, rozpoczynające moduł kształcenia dotyczący diagnozy i terapii osób z rozszczepem. Są one następujące:

- wiedza:

- teoria zaburzeń mowy, w tym w szczególności różne typologie zaburzeń mowy, profilujące zaburzenia realizacji fonemów;

- różnice pomiędzy tradycyjnym a nowym ujęciem dyslalii z perspektywy diagnozy i terapii zaburzeń realizacji fonemów;

- patofonetyka zaburzeń realizacji fonemów;

- budowa i fizjologia narządów mowy, w szczególności podniebienia, jamy nosowej, układu adenoidalnego;

- podstawy ortodoncji;

- podstawy laryngologii;

- podstawy foniatrii;

- podstawy audiologii;

- objawy opóźnionego rozwoju mowy oraz różne przyczyny tego zaburzenia, w tym o charakterze społecznym i psychologicznym;

- podstawy wczesnej interwencji logopedycznej;

- umiejętności:

- praktyczne umiejętności badania realizacji fonemów z wykorzystaniem metody analityczno-fonetycznej, z uruchomieniem strategii słuchowo-wzrokowo-czuciowo-eksperymentalnej; 
- praktyczne umiejętności badania czynności prymarnych;

- umiejętność dostrzegania związków przyczynowo-skutkowych pomiędzy rodzajem warunków realizacyjnych (anatomicznych i czynnościowych) oraz percepcyjnych a formą zaburzeń systemu fonemowo-fonetycznego; rozumienie mechanizmu wad wymowy w przypadku dyslalii ankyloglosyjnej, dyslalii zgryzowej, dyslalii słuchowej, dyslalii wynikającej z zaburzeń czynności prymarnych; umiejętność projektowania i prowadzenia terapii logopedycznej w przypadku wskazanych form dyslalii;

- rozumienie istoty współpracy pomiędzy logopedą a ortodontą, laryngologiem, audiologiem, foniatrą;

- kompetencje społeczne:

- umiejętność udzielania wsparcia emocjonalnego rodzicom dzieci z zaburzeniami mowy;

- umiejętność udzielania wsparcia emocjonalnego dzieciom z trudnościami emocjonalnymi związanymi z funkcjonowaniem w grupie rówieśniczej;

- poczucie odpowiedzialności za stosowane wobec pacjenta z zaburzeniami mowy zabiegi logopedyczne;

- dążenie do stałego wzbogacania własnej wiedzy na temat różnych zaburzeń mowy.

\section{Wiedza lingwistyczna, medyczna, psychologiczna i logopedyczna jako podstawa diagnozy i terapii zaburzeń mowy u osób z rozszczepem wargi i/lub podniebienia}

Wada rozszczepowa powstaje w pierwszym trymestrze ciąży i jest efektem - mówiąc w uproszczeniu - niezrośnięcia się pewnych elementów składających się na wargę górną i podniebienie ${ }^{3}$, w obliczu występowania niekorzystnych czynników genetycznych i środowiskowych, które poprzez organizm matki działają na rozwijający się zarodek w określonych tygodniach pierwszego trymestru ciąży. Szczelina w obrębie wargi i podniebienia w znaczący sposób zmienia wygląd twarzy dziecka, powoduje trudności w pobieraniu pokarmów, zmienia model oddychania, a co za tym idzie - wpływa na rozwój mowy i komunikację. Zaburzenia mowy u osób z rozszczepem przyjmują charakterystyczne formy, co ma związek w szczególności z jakością struktur objętych wadą, efektami leczenia chirurgicznego, działaniem czynników jatrogennych, występującymi wadami zgryzu i niedosłuchem oraz zaburzeniami czynności biologicznych. Istotne mogą być także uwarunkowania emocjonalno-społeczne związane z trudnym dla niektórych dzieci czasem związanym z operacją

3 Patomechanizm powstawania wady rozszczepowej jest znacznie bardziej skomplikowany, niż wynika to $\mathrm{z}$ przedstawionego $\mathrm{w}$ zdaniu opisu. Informacje na ten temat można znaleźć $\mathrm{w}$ opracowaniach ortodontycznych czy też dotyczących embriologii. 
chirurgiczną, niezrozumiałością mowy, odmiennym wyglądem twarzy czy nieprawidłową stymulacją rozwoju mowy małego dziecka z rozszczepem.

Rodzice, którym urodziło się lub ma się urodzić dziecko z rozszczepem, nierzadko są załamani i bardzo przeżywają zaistniałą sytuację. Leczenie dziecka z rozszczepem trwa przez wiele lat i biorą w nim udział: chirurg, ortodonta, laryngolog, audiolog, foniatra, a także logopeda. Osoby z rozszczepem mogą - lecz nie muszą - mieć trudności emocjonalno-społeczne konstytuujące się na przykład w związku z mniej lub bardziej zmienionym wyglądem twarzy oraz niezrozumiałą mową. Działania pomocowe muszą zatem uwzględniać wskazania medyczne, a także psychologiczne oraz ściśle związane z metodyką diagnozy i terapii logopedycznej. Bazą postępowania logopedycznego jest wiedza lingwistyczna i medyczna dotycząca istoty zaburzeń mowy, uwzględniająca także wytyczne o charakterze psychologicznym.

Powyższe uwagi stają się ogólnym tłem dla określenia podstawowej wiedzy, jaką należy przekazać studentom logopedii podczas kształcenia dotyczącego postępowania $\mathrm{z}$ osobami $\mathrm{z}$ rozszczepem. Wymienione poniżej zagadnienia $\mathrm{w}$ żadnym razie nie wyczerpują problematyki etiologii, mechanizmu powstawania wady w obrębie środkowej części twarzoczaszki, istoty zaburzeń mowy i komunikacji, a także lingwistycznych podstaw prowadzenia diagnozy i terapii logopedycznej. Nakreślają jedynie ogólną kanwę koniecznej do realizacji tematyki. Są one następujące:

- etiopatogeneza wady rozszczepowej;

- różne typologie rozszczepów wargi i/lub podniebienia;

- zaburzenia anatomiczne i czynnościowe w przypadku rozszczepu;

- wielospecjalistyczne leczenie osób z rozszczepem i rola logopedy;

- skutki wady rozszczepowej dla rozwoju mowy, komunikacji oraz rozwoju emocjonalno-społecznego;

- kierunki rozwoju mowy dziecka z rozszczepem;

- objawy i przyczyny dyslalii rozszczepowej oraz alalii rozszczepowej;

- patofonetyka mowy rozszczepowej;

- diagnoza różnicowa;

- logopedyczna diagnoza pacjenta z rozszczepem;

- kategorie wczesnej interwencji logopedycznej w przypadku dzieci z rozszczepem;

- postępowanie logopedyczne z dzieckiem po urodzeniu, przed i po operacji chirurgicznej oraz w kolejnych latach życia dziecka, a także z rodzicami nienarodzonego dziecka $\mathrm{z}$ wadą $\mathrm{w}$ obrębie środkowej części twarzoczaszki;

- postępowanie logopedyczne w przypadku dyslalii rozszczepowej i alalii rozszczepowej;

- postępowanie logopedyczne w przypadku nosowania otwartego strukturalnego i funkcjonalnego;

- miejsce i rola logopedy w wielospecjalistycznym leczeniu dzieci z rozszczepem wargi i podniebienia; istota interdyscyplinarności logopedii. 


\section{Umiejętności praktyczne}

Na bazie wiedzy przekazywanej w toku wykładów i ćwiczeń, a także jednocześnie odbywających się praktyk w ośrodku leczenia wady rozszczepowej lub w poradni przyjmującej dzieci z wadą rozszczepową studenci powinni zdobyć co najmniej następujące umiejętności:

- rozpoznawanie podczas diagnozy zaburzeń rezonansu, realizacji poza jamą ustną oraz współruchów mimicznych twarzy;

- analiza mechanizmu zaburzeń realizacji fonemów, co oznacza powiązanie objawu zaburzeń ze stanem procesów percepcyjnych i realizacyjnych;

- projektowanie i prowadzenie terapii logopedycznej w zależności od wyników diagnozy, w szczególności różnicowania dyslalii rozszczepowej i alalii rozszczepowej;

- postępowanie $\mathrm{z}$ dzieckiem $\mathrm{z}$ nosowaniem otwartym;

- postępowanie $\mathrm{z}$ noworodkiem, niemowlęciem i dzieckiem $\mathrm{w}$ wieku poniemowlęcym;

- praca $\mathrm{z}$ rodzicami nienarodzonego dziecka $\mathrm{z}$ rozszczepem.

\section{Kompetencje społeczne}

Do szczególnych kompetencji społecznych, jakie należy wykształcić u logopedy, należą:

- umiejętność udzielania wsparcia emocjonalnego rodzicom dzieci z zaburzeniami mowy na różnych etapach rozwoju dziecka z wadą rozszczepową, także w przypadku nienarodzonego dziecka;

- umiejętność udzielania wsparcia emocjonalnego osobom z rozszczepem, potrzebującym takiej pomocy w związku z przeżywanymi trudnościami emocjonalno-społecznymi na tle wyglądu własnej twarzy i mowy, które mogą - ale nie muszą - pojawić się w toku rozwoju dziecka;

- poczucie odpowiedzialności za zdrowie i życie dziecka z rozszczepem w obliczu stosowanych zabiegów logopedycznych, związanych na przykład z karmieniem małego dziecka czy podejmowaniem - wraz z chirurgiem i foniatrą - kluczowych decyzji dotyczących operacji chirurgicznych, na przykład faryngoplastyki;

- dążenie do stałego wzbogacania własnej wiedzy na temat wady rozszczepowej i sposobów jej leczenia w obliczu nowych badań medycznych i logopedycznych. 


\section{Zakończenie}

Przygotowany projekt może być podstawą opracowania szczegółowego modelu kształcenia w zakresie diagnozy i terapii zaburzeń mowy osób z rozszczepem wargi i/lub podniebienia w Polsce. Szczegółowe prace koncepcyjne powinny toczyć się w gronie logopedów, którzy mają doświadczenie w praktycznej diagnozie i terapii osób z rozszczepem, ale również - co byłoby wskazane - zajmują się omawianą dysfunkcją mowy także naukowo. Kolejny postulat wiąże się z potrzebą ilustrowania omawianych treści fotografiami i filmami, jak również z uczestnictwem studentów $\mathrm{w}$ bezpośrednich zajęciach $\mathrm{z}$ pacjentami w ośrodku leczenia wady rozszczepowej lub w poradni. Trudno jest uczyć diagnozy i terapii bez analizy konkretnych przykładów pacjentów z zaburzeniami mowy.

Ostatni z postulatów - dotyczący praktyk - nie jest łatwy do realizacji. Wydaje się, że chociaż w ciągu ostatnich kilkunastu lat system kształcenia logopedów w Polsce bardzo się zmienił i obejmuje znaczną ilość praktyk, to jednak zabezpieczenie odpowiednich miejsc odbywania się zajęć tego typu nie jest sprawą prostą.

Znam wielu absolwentów logopedii, którzy nie podejmują pracy w zawodzie. Jako jedną z przyczyn część z nich podaje niepewność co do własnej wiedzy, a przede wszystkim niedosyt umiejętności praktycznych. Myślę, że rozwiązaniem tego problemu mógłby być co najmniej roczny staż realizowany już po otrzymaniu dyplomu ukończenia studiów logopedycznych. Jego idea mogłaby być następująca: absolwent logopedii prowadzi samodzielnie diagnozę i terapię logopedyczną, ale pod okiem i kierunkiem doświadczonego logopedy, który jest jego opiekunem. Logopeda uczestniczy także w zajęciach prowadzonych przez swojego opiekuna, wykonuje pod jego okiem diagnozę i terapię logopedyczną, korzysta z jego konsultacji, na bieżąco jest prowadzona superwizja. Przedstawiony model stażu umożliwiałby młodemu logopedzie ugruntowanie wiedzy i umiejętności praktycznych oraz bezpieczne wejście w samodzielne decyzje diagnostyczne i terapeutyczne. Czy jest to możliwe? Jeśli tak, to kiedy? Jeśli nie, to dlaczego?

Nie znam dokładnej odpowiedzi na te pytania. Myślę jednak, że istotne jest formułowanie postulatów, projektów, kreślenie wizji budujących nowy model kształcenia. Jestem przekonana, że kiedyś ten projekt zostanie zrealizowany. 
Literatura

Antkowski F., 1957, Patologia mowy w przypadkach „palatoschisis”, „Biuletyn Fonograficzny”, nr 2, s. $27-45$.

Antkowski F., 1960, Uwagi o rehabilitacji (retranspozycji) mowy, „Biuletyn Fonograficzny”, nr 3, s. $59-65$.

Emiluta-Rozya D., 2012, Formy zaburzeń mowy, [w:] S. Grabias, M. Kurkowski (red.), Logopedia. Teoria zaburzeń mowy, Lublin: Wydawnictwo Uniwersytetu Marii Curie-Skłodowskiej, s. $73-87$.

Grabias S., 2012, Teoria zaburzeń mowy. Perspektywy badań, typologie zaburzeń, procedury postępowania logopedycznego, [w:] S. Grabias, M. Kurkowski (red.), Logopedia. Teoria zaburzeń mowy, Lublin: Wydawnictwo Uniwersytetu Marii Curie-Skłodowskiej, s. 15-71.

Grabias S., 2015, Postępowanie logopedyczne. Standardy terapii, [w:] S. Grabias, J. Panasiuk, T. Woźniak (red.), Logopedia. Standardy postępowania logopedycznego. Podręcznik akademicki, Lublin: Wydawnictwo Uniwersytetu Marii Curie-Skłodowskiej, s. 13-38.

Grabias S., 2019, Język w zachowaniach społecznych. Podstawy socjolingwistyki i logopedii, Lublin: Wydawnictwo Uniwersytetu Marii Curie-Skłodowskiej.

Hardin-Jones M.A., Jones D.L., 2005, Speech production of preschoolers with cleft palate, „The Cleft Palate-Craniofacial Journal", vol. 42(1), s. 7-13.

Hortis-Dzierzbicka M., 2004, Nasofiberoskopia w ocenie zastosowania płata gardłowego $w$ niewydolności podniebienno-gardłowej u pacjentów z rozszczepem podniebienia, Warszawa: Wydawnictwo Medyczne Borgis.

Kuehn D.P., Karlind T. M., 2000, Speech and Language Issues in the Cleft Palate Population: The State of the Art, „Cleft Palate - Craniofacial Journal”, vol. 37, no. 4, s. 348-1-348-35.

Kwiecień A., Dudkiewicz Z., 1996, Charakterystyka mowy dzieci z różnymi typami rozszczepu wargi i podniebienia, [w:] Z. Dudkiewicz (red.), II konferencja robocza - rehabilitacja mowy. Rozszczep wargi i podniebienia, Warszawa: Instytut Matki i Dziecka, Klinika Chirurgii Dzieci i Młodzieży, s. 24-32.

Łyżyczka I., 1978, Metody rehabilitacji wymowy u dzieci z rozszczepem podniebienia, „Logopedia”, nr 13, s. 53-57.

Mierzejewska H., Emiluta-Rozya D., 1997, Projekt zestawienia form zaburzeń mowy, „Audiofonologia”, t. 10, s. 37-48.

Nikhila K.G., Prasad H., 2017, A Study on Patterns of Compensatory Articulation Errors with Reference to Age of Surgery in Children with Repaired Cleft Lip and Palate, „Global Journal of Otolaryngology", vol. 7(2), s. 15-30, https://juniperpublishers.com/gjo/GJO.MS.ID.555706 .php (dostęp: 26.07.2021).

Ostapiuk B., 2013a, Dyslalia. O badaniu jakości wymowy w logopedii, Szczecin: Wydawnictwo Naukowe Uniwersytetu Szczecińskiego.

Ostapiuk B., 2013b, Dyslalia ankyloglosyjna. O krótkim wędzidełku języka, wadliwej wymowie i skuteczności terapii, Szczecin: Wydawnictwo Naukowe Uniwersytetu Szczecińskiego.

Pluta-Wojciechowska D., 2006, Zaburzenia mowy u dzieci z rozszczepem podniebienia. Badania - Teoria - Praktyka, Bielsko-Biała: Wydawnictwo ATH.

Pluta-Wojciechowska D., 2010, Podstawy patofonetyki mowy rozszczepowej. Dyslokacje, Bytom: Wydawnictwo Ergo-Sum.

Pluta-Wojciechowska D., 2011, Mowa dzieci z rozszczepem wargi i podniebienia, Kraków: Wydawnictwo Naukowe Uniwersytetu Pedagogicznego.

Pluta-Wojciechowska D., 2013, Logopedyczne i foniatryczne ujęcie zakłóceń dźwięków mowy. Analiza kognitywna, „Nowa Audiofonologia”, t. 2, nr 3, s. 9-15. 
Pluta-Wojciechowska D., 2015, Standard postępowania logopedycznego w przypadku rozszczepu wargi i podniebienia, [w:] S. Grabias, J. Panasiuk, T. Woźniak (red.), Logopedia. Standardy postępowania logopedycznego. Podręcznik akademicki, Lublin: Wydawnictwo Uniwersytetu Marii Curie-Skłodowskiej, s. 727-779.

Pluta-Wojciechowska D., 2019a, Efektywność terapii dyslalii. Logopedyczno-lingwistyczna analiza wyników badań, Katowice: Wydawnictwo Uniwersytetu Śląskiego.

Pluta-Wojciechowska D., 2019b, Orofacjologopedia, „Logopedia”, nr 49, s. 137-158.

Pluta-Wojciechowska D., 2020, Terapia strategiczna dyslalii obwodowej. Inspiracje do ćwiczeń wargi i języka dla dzieci oraz dorostych, Bytom: Wydawnictwo Ergo-Sum.

Styczek I., 1981, Logopedia, Warszawa: Państwowe Wydawnictwo Naukowe.

Trost J.E., 1981, Articulatory additions to the classical description of the speech of persons with cleft palat, „Cleft Palate Journal”, no. 18, s. 193-203.

Wyatt R., Sell D., Russell J., Harding A., Harland K., Albery E., 1996, Cleft palate speech dissected: a review of current knowledge and analysis, „British Journal of Plastic Surgery”, no. 49, s. $143-149$.

\begin{tabular}{|l|l|}
\hline CC & $\begin{array}{l}\text { C by the author, licensee Łódź University - Łódź University Press, Łódź, Poland. } \\
\text { This article is an open access article distributed under the terms and conditions } \\
\text { of the Creative Commons Attribution license CC-BY-NC-ND } 4.0 \\
\text { (https://creativecommons.org/licenses/by-nc-nd/4.0/) }\end{array}$ \\
\hline Data złożenia: 5.04.2021. Data przyjęcia: 17.06.2021.
\end{tabular}

